\title{
Redefining Retail Store Formats - A South African Study
}

\author{
Rajesh Sharma ${ }^{1}$, Abhinanda Gautam ${ }^{2}$ \\ ${ }^{1}$ Senior Facilitator Regenesys Business School, South Africa \\ ${ }^{2}$ Academic Head Regenesys Business School, South Africa \\ Correspondence: Dr. Abhinanda Gautam, Academic Head Regenesys Business School, South Africa.
}

Received: March 26, 2016

doi:10.11114/afa.v3i2.2518
Accepted: May 30, $2017 \quad$ Available online: June 28, 2017

URL: https://doi.org/10.11114/afa.v3i2.2518

\begin{abstract}
The global competitive retail space is challenging and the retailers are experimenting with different strategies to gain competitive advantage in the market. Retailers are developing and designing new and improved store formats to mirror the customers' expectations by using distinctive benefits. Thus attracting and retaining customers by creating store brand loyalty is every retailer's dream and they are spending a huge amount of time and money in developing these uniquely attractive retail store formats. However, limited academic research is available to help retailers understand the most profitable and popular retail store format in South Africa.

This empirical research paper is an attempt to investigate the influence of the design, type and size of the retail store on the customer buying behaviour in the consumer durables market by examining a random sample of respondents from Gauteng, South Africa. The research findings, indicates that there is a varying degree of effect of retail store formats on the customer buying behaviour. Most of the variables have a positive correlation with other variables of customer behaviour. However in some cases, variables have significant inverse relationship with each other.
\end{abstract}

Keywords: retail store formats, customer buying behaviour, consumer durables market, South Africa

\section{Introduction}

"Competition in the retailing industry has reached dramatic dimensions. New retailing formats appear in the market increasingly more rapidly. A focus on a particular aspect of the retail mix (e.g., service or price) means that retailers can compete on highly diverse dimensions. Scrambled merchandising and similar developments have implied that particular retailers are now competing against retailers they did not compete with in the past" Leszczyc, Sinha and Timmermans (2000). The South African market is a testimony of such a competitive landscape and as Kearney, 2014 report on Africa suggests, "Modern retail accounts for more than 60 percent of sales in South Africa, led by local chain Shoprite. Supermarkets dominate the market thanks to substantial investment; hypermarkets have spread a little more slowly but cater to more affluent classes." The report further suggests, "bulk purchases are increasing, and store size, look and feel, and assortments are growing more important." The changing retail dynamics of South African market fuelled by a growing middle class population is attracting the global retailers, who along with the local retailers are experimenting with the retail formats to attract and retain the customers.

"The South African retail sphere offers attractive growth opportunities, which suggests that major changes in this sector are imminent. National retail companies such as Pick 'n Pay, Shoprite and Spar are aiming to expand over the next few years by increasing their number of retail outlets in South Africa" Marais, Klerk and Dye (2014). "As a certain result, store choice and patronage decision have been widely studied to serve for the need of understanding and developing the retail industry in many countries" Nguyen, Vu and Zhang (2010). Little empirical research is available in South Africa to help guide the retailers in selecting the most appropriate retail format in the consumer durables market.

This research paper aims to study the influence of the design, type and size of the retail store on the customer buying behaviour in the consumer durables market of South Africa.

\section{Literature Review}

"A store format has been defined as the mix of variables that retailers use to develop their business strategies and constitute the mix as assortment, price, and transactional convenience and experience" Messinger and Narsimhan (1997). Levy and Weitz (2002) defines a store format as a type of retail mix. Customers assess these different retail 
store formats and patronize them for the purchase of different types of goods. Hansen, Cumberland and Solgaard (2012) suggests that there can be a number of different dimensions which are potentially significant for the customer's assessment of individual stores.

An important dimension of the retail store choice is the age of the customer. "Young consumers, interestingly, lend to shop not from a utilitarian perspective but from a hedonistic perspective. Their key indulgence includes getting product ideas or meeting friends. They also view shopping as a means of diversion to alleviate depression or break the monotony of daily routine. In addition to this, they also go shopping to have fun or just browse through the outlets" Kiran and Jhamb (2011). Store location, attributes, environment and prices are other important dimensions that are found in store choice literature.

Bell, Ho and Tang (1998) also believe that shoppers are influenced predominantly by store location and travel distance. However Grewal, Krishnan, Baker and Borin (1998) opines that the three important components that appear to be key to store patronage decisions are the retailer's store image, quality of the merchandise/brands sold and price/promotions. Discussing other important dimensions, Singh, Katiyar and Verma (2014) suggests that retail store atmospherics \& design is also highly associated with future consumption behaviour in terms of the customers' intention to visit, purchase and recommend the store to family and friends. Liao, Liaw, and Jen (2011) further supports the argument and states that the design of the store environment is generally the first visual sensation noticed by the consumer.

Baker, Levy and Grewal (1992) suggests that in a time when retailers are finding it increasingly difficult to create a differential advantage on the basis of merchandise, price, promotion, and location, the store itself becomes a fertile opportunity for market differentiation. However Fox, Postrel and McLaughlin (2007) maintains that unlike a bad pricing or promotional decision, a poor store location adversely affects retailer performance for several years. But as Sinha and Kar (2007) suggests it is important for retailer to look at local conditions and insights into the local buying behavior before shaping the format choice.

"Now a number of retailers are in a mode of experimentation and trying several formats which are essentially representation of retailing concepts to fit into the consumer mind space" Sinha and Kar (2007). This has intensified the competition and as a result "marketing strategies are changing too. Grocery retailers are developing new store formats aimed to capture the competitor's customers and expand their target market: discounters are improving the quality of the service to compete with the supermarkets and hypermarkets are developing lower pricing policies to compete with discounters" Bellini and Cardinali (2015).

\section{Research Design and Methodology}

As their first step in the research process the researchers identified the retail store formats offering consumer durables in the Johannesburg market through the desk research. The retail store formats considered for the research are presented below in Table 1.

Table 1. Retail Store Formats Considered in the Consumer Durables Segment

\begin{tabular}{|c|c|c|}
\hline S. No. & Sector & Retail store formats considered \\
\hline 1. & Consumer & Super Markets, Super Stores, Hyper Markets \\
\hline \multicolumn{3}{|c|}{$\begin{array}{l}\text { As a next step in the research process, the elements of customer buying behaviour which are predominantly considered } \\
\text { by retailers and marketers were identified from the literature review and as recommended by Shi, Cheung and } \\
\text { Prendergast (2005) involves stock piling (SP), purchase acceleration (PA), brand switching (BS), spending more(SM) } \\
\text { and product trial (PT). Researchers included the sixth element of store visit (SV) in the study. }\end{array}$} \\
\hline \multicolumn{3}{|c|}{$\begin{array}{l}\text { The next step was to decide on the sample size and sampling technique for collecting the primary data. For this study, } \\
\text { the data was collected by convenience sampling method, which involved a structured and specifically designed } \\
\text { questionnaire. The copies of the questionnaire were distributed to } 115 \text { students of } 25-55 \text { years age group in a college } \\
\text { based in Gauteng, Johannesburg and the data was collected by personal interview in the form of written responses to the } \\
\text { questionnaire. } 19 \text { copies of the questionnaire were ignored from the final analysis, as they were not properly/ } \\
\text { completely filled. The questionnaire comprised of } 13 \text { questions which were divided in three sections-A, B \& C. } \\
\text { Section-A sought to obtain the respondents' demographic information while the Section-B ensured that the respondents } \\
\text { are representative of the target population, conscious of the different retail store formats offering consumer durables. In } \\
\text { cases where the response was negative, the data collection interview was terminated and the questionnaire was } \\
\text { discarded. Section-C consisted of } 6 \text { questions on a 5-point Likert Scale ranging from } 1 \text { 'Never' to } 5 \text { 'Always', which } \\
\text { assisted the research study to gain insight into the customers' behaviour towards different retail store formats. The } \\
\text { questions examined the most likely consumer response towards a retail store format. }\end{array}$} \\
\hline
\end{tabular}

The purpose of the study was to identify the effect of retail formats on the customer buying behaviour in the consumer durables market. A specific customer behavioural response may be induced by more than one type of a retail format. For 
instance, a Hyper Market, a Specialty Store or a Discount Store may induce product trial. Likewise, a particular retail format may induce more than one type of customer behavioural response. For example, a Discount Store may induce spending more, product trial and store visit too. Thus the following hypothesis was developed to be tested-

$\mathrm{H}_{0}$ : Retail store format has no significant effect on the customer buying behaviour in the consumer durables market.

$\mathrm{H}_{1:}$ Retail store format has a significant effect on the customer buying behaviour in the consumer durables market.

Running from the hypothesis, the following key variables were formulated: It is to note that the researcher has represented the Variables as (V) and they are used as (VA, VB, VC, VD, VE, VF) across the tables used in the paper. The six variables of customer buying behaviour was abridged for the purpose of the study as under-

VA- Visit Retail store for purchase

VB- Visit retail store for trying a new product

VC- Retail store induces more expenditure

VD- Retail store induces brand switching

VE- Retail store accelerates purchases

VF- Retail store induces stock piling

The degree of relationship between aforementioned variables was studied using correlation analysis. After establishing the relationship between variables, their association was also analysed using Chi Square test. A further in-depth analysis was also conducted using Z-Test to study the overall impact of retail formats on the customer buying behaviour.

The internal consistency of the data was verified using Cronbach alpha.

\section{Empirical Findings and Discussion}

Alpha was developed by Lee Cronbach in 1951 to provide a measure of the internal consistency of a test or scale; it is expressed as a number between 0 and 1. According to Tavakol and Dennick (2011), internal consistency explains the degree to which all the items in a test measure the same concept or construct and hence it is connected to the inter-relatedness of the items within the test. In addition, reliability evaluations show the amount of measurement error in a test.

The internal consistency in the different types of retail stores under study was calculated using Cronbach Alpha and is presented in the Table 2.

Table 2. Cronbach Alpha

\begin{tabular}{lll}
\hline S.NO. & TYPES OF STORES & CRONBACH $\boldsymbol{\alpha}$ \\
\hline 1 & Super Markets & 0.81 \\
2 & Super Stores & 0.94 \\
3 & Hypermarkets & 0.93 \\
4 & Warehouse Store & 0.82 \\
5 & Departmental Store & 0.79 \\
6 & Discount Store & 0.96 \\
7 & Flea Market & 0.9 \\
8 & Speciality Stores & 0.89 \\
\hline
\end{tabular}

For the demonstration of internal consistency of new scales and established scales $\alpha$ value of 0.6 and 0.7 is considered significant. The Cronbach alpha calculated in the Table 2 above shows a high value for all the retail stores, especially super stores (0.94), hypermarkets (0.93) and discount stores (0.96). This indicates the reliability of the scales is reasonably high, and hence suggests a high internal consistency among the measurement items.

\subsection{Evaluation of Relationship between Key-mediating Variables of Consumer Behaviour (CB) on Respondents'Scores}

Correlation coefficients are measures of the degree of relationship between two or more variables. It is the discussion of relationship about the way in which the variables tend to vary together. In order to confirm the impact of variables on the customer buying behavior, the research made an endeavour to understand the degree of relationship between variables with respect to each identified retail store of South Africa. 
Table 3.1. Degree of Relationship between Key-Mediating Variables in Super Markets

\begin{tabular}{lllllll}
\hline CB Variables & VA & VB & VC & VD & VE & VF \\
\hline VA & $\mathbf{1}$ & $0.91^{* *}$ & $0.78^{* *}$ & $0.74^{* *}$ & 0.07 & $0.86^{* *}$ \\
VB & & $\mathbf{1}$ & $0,75^{* *}$ & $0.94^{* *}$ & 0.26 & $0.82^{* *}$ \\
VC & & $\mathbf{1}$ & $0.59^{*}$ & $0.43^{*}$ & $0.80^{* *}$ \\
VD & & & $\mathbf{1}$ & $0.42^{*}$ & $0.62^{* *}$ \\
VE & & & & $\mathbf{1}$ & -0.11 \\
VF & & & & & $\mathbf{1}$ \\
\hline
\end{tabular}

**Correlation is significant at 0.01 level, (2-tailed); * Correlation is significant at 0.05 level (2-tailed)

Table 3.1 exhibits the degree of relationship between key mediating variables of consumer behaviour. The table illustrates that the correlation in most of the variables is highly significant. However the correlation between VA and VE (.07), VB and VE (.25) and VF and VE (-0.11) is insignificant. This suggests that in case of Super Markets, VE has insignificant correlation with the other variables of consumer behaviour.

Table 3.2. Degree of Relationship between Key-Mediating Variables in Super Stores

\begin{tabular}{lllllll}
\hline CB Variables & VA & VB & VC & VD & VE & VF \\
\hline VA & $\mathbf{1}$ & $0.92^{* *}$ & $0.90^{* *}$ & $0.55^{*}$ & $0.93^{* *}$ & $0.55^{*}$ \\
VB & & $\mathbf{1}$ & $0.84^{* *}$ & 0.28 & $0.82^{* *}$ & $0.74^{* *}$ \\
VC & & $\mathbf{1}$ & $0.45^{*}$ & $0.98^{* *}$ & 0.36 \\
VD & & & $\mathbf{1}$ & $0.60^{* *}$ & -0.30 \\
VE & & & & $\mathbf{1}$ & 0.28 \\
VF & & & & & $\mathbf{1}$
\end{tabular}

**Correlation is significant at 0.01 level, (2-tailed); * Correlation is significant at 0.05 level (2-tailed)

The Table 3.2 shows that although the correlation between most of the variables is highly significant, some of them have insignificant correlation. The correlation between VB and VD (.28) is highly insignificant. The correlation between VD and VF (-0.3) and VC and VF (0.36) is insignificant. Similarly, variable VF has an insignificant correlation with other variables of consumer behaviour.

Table 3.3. Degree of Relationship between Key-Mediating Variables in Hyper Markets

\begin{tabular}{lllllll}
\hline CB & VA & VB & VC & VD & VE & VF \\
\hline VA & $\mathbf{1}$ & $0.94^{* *}$ & $0.94^{* *}$ & $0.87^{* * *}$ & 0.36 & $0.62^{* *}$ \\
VB & & $\mathbf{1}$ & $0.94^{* *}$ & $0.85^{* *}$ & 0.27 & 0.55 \\
VC & & & $\mathbf{1}$ & $0.97^{* *}$ & 0.37 & $0.74^{* *}$ \\
VD & & & & $\mathbf{1}$ & 0.23 & $0.68^{* *}$ \\
VE & & & & & $\mathbf{1}$ & $0.83^{* *}$ \\
VF & & & & & & $\mathbf{1}$ \\
\hline
\end{tabular}

**Correlation is significant at 0.01 level, (2-tailed); * Correlation is significant at 0.05 level (2-tailed)

Table 3.3 reflects the degree of relationship between key mediating variables of consumer behaviour with special reference to Hypermarkets of South Africa The table shows that variables have highly significant correlation with each other. However variable VE suffers from insignificant degree of relationship with most of the variables. VA (0.36), VB (0.27), VC (0.37), VD (0.23). Conversely VF and VE (0.83) have highly significant relation.

Table 3.4. Degree of Relationship between Key-Mediating Variables in Warehouse Stores

\begin{tabular}{lllllll}
\hline CB Variables & VA & VB & VC & VD & VE & VF \\
\hline VA & $\mathbf{1}$ & $0.57^{*}$ & $0.74^{* *}$ & $0.93^{* *}$ & $0.50^{* *}$ & $0.77^{* *}$ \\
VB & & $\mathbf{1}$ & $0.68^{* *}$ & $0.71^{* *}$ & 0.15 & $0.70^{* *}$ \\
VC & & $\mathbf{1}$ & $0.84^{* *}$ & $0.73^{* *}$ & $0.69^{* *}$ \\
VD & & & $\mathbf{1}$ & 0.39 & $0.93^{* *}$ \\
VE & & & & $\mathbf{1}$ & 0.08 \\
VF & & & & & $\mathbf{1}$ \\
\hline
\end{tabular}

**Correlation is significant at 0.01 level, (2-tailed); * Correlation is significant at 0.05 level (2-tailed) 
Table 3.4 reflects the degree of relationship between key mediating variables of consumer behaviour with special reference to Warehouse stores of South Africa. It shows a very significant degree of relationship between variables of consumer behaviour and significant with respect to Warehouse store. However variable VF has insignificant correlation with VB (0.15), VD (0.39) and VF (0.08).

Table 3.5. Degree of Relationship between Key-Mediating Variables in Departmental Stores

\begin{tabular}{lllllll}
\hline CB Variables & VA & VB & VC & VD & VE & VF \\
\hline VA & $\mathbf{1}$ & $0.86^{* *}$ & $0.69^{* *}$ & 0.29 & $-0.67^{* *}$ & 0.09 \\
VB & & $\mathbf{1}$ & $0.95^{* *}$ & 0.40 & -0.30 & 0.25 \\
VC & & $\mathbf{1}$ & 0.30 & -0.14 & 0.17 \\
VD & & & $\mathbf{1}$ & $0.40^{*}$ & $0.83^{* *}$ \\
VE & & & & $\mathbf{1}$ & $0.56^{*}$ \\
VF & & & & & $\mathbf{1}$
\end{tabular}

**Correlation is significant at 0.01 level, (2-tailed); * Correlation is significant at 0.05 level (2-tailed)

The Table 3.5 shows that the correlation between most of the variables is not significant. The degree of relationships between VA and VD (0.29), VA and VF (0.09) is insignificant. The correlation between VB and V6 (0.25) is insignificant. The degree of relationships of VC is highly insignificant with VE (-0.14) and V6 (0.17)

Table 3.6. Degree of Relationship between Key-Mediating Variables in Discount Stores

\begin{tabular}{lllllll}
\hline CB Variables & VA & VB & VC & VD & VE & VF \\
\hline VA & $\mathbf{1}$ & $0.51^{*}$ & $0.76^{* *}$ & $0.73^{* *}$ & $0.47^{*}$ & $0.44^{*}$ \\
VB & & $\mathbf{1}$ & $0.70^{* *}$ & $0.40^{*}$ & $0.97^{* *}$ & $0.73^{* *}$ \\
VC & & $\mathbf{1}$ & 0.34 & $0.77^{* *}$ & $0.58^{*}$ \\
VD & & & $\mathbf{1}$ & 0.22 & $0.67^{* *}$ \\
VE & & & & $\mathbf{1}$ & $0.63^{* *}$ \\
VF & & & & & $\mathbf{1}$ \\
\hline
\end{tabular}

**Correlation is significant at 0.01 level, (2-tailed); * Correlation is significant at 0.05 level (2-tailed)

It is established in the Table 3.6 that the degree of relationship between variables of consumer behaviour is highly significant .It is evident that there is only one insignificant correlation, i.e. between VD and VF (0.22) in the table.

Table 3.7. Degree of Relationship between Key-Mediating Variables in Flea Markets

\begin{tabular}{lllllll}
\hline CB Variables & VA & VB & VC & VD & VE & VF \\
\hline VA & $\mathbf{1}$ & $0.86^{* *}$ & $0.85^{* *}$ & $0.79^{* *}$ & $0.79^{* *}$ & $0.83^{* *}$ \\
VB & & $\mathbf{1}$ & $0.90^{* *}$ & $0.71^{* *}$ & $0.89^{* *}$ & $0.73^{* *}$ \\
VC & & $\mathbf{1}$ & $0.92^{* *}$ & $0.94^{* *}$ & $0.94^{* *}$ \\
VD & & & $\mathbf{1}$ & $0.76^{* *}$ & $0.98^{* *}$ \\
VE & & & & 1 & $0.84^{* *}$ \\
VF & & & & & $\mathbf{1}$ \\
\hline
\end{tabular}

**Correlation is significant at 0.01 level, (2-tailed); * Correlation is significant at 0.05 level (2-tailed)

It is exhibited in the Table 3.7 that the degree of relationships between the variables is highly significant with each other, with reference to the Flea Markets of South Africa.

Table 3.8. Degree of Relationship between Key-Mediating Variables in Specialty Stores

\begin{tabular}{lllllll}
\hline CB Variables & VA & VB & VC & VD & VE & VF \\
\hline VA & $\mathbf{1}$ & $0.86^{* * *}$ & $0.60^{* * *}$ & $-0,07$ & $0.60^{* *}$ & $0.89^{* *}$ \\
VB & & $\mathbf{1}$ & $0.80^{* *}$ & $-0,17$ & $0.90^{* *}$ & $0.60^{* *}$ \\
VC & & $\mathbf{1}$ & 0,34 & $0.78^{* *}$ & 0.17 \\
VD & & & $\mathbf{1}$ & -0.31 & -0.29 \\
VE & & & & $\mathbf{1}$ & 0.29 \\
VF & & & & & $\mathbf{1}$ \\
\hline
\end{tabular}

**Correlation is significant at 0.01 level, (2-tailed); * Correlation is significant at 0.05 level (2-tailed) 
It is discovered in the Table 3.8 that in case of Specialty Store, the degree of relationship between most of the variables of consumer behaviour is highly significant. However the correlation between VB and VD (-0.17), VC and VF (0.17), VA and VD (-0.07), VD and VF (-0.29) is highly insignificant.

The collected data was further analysed in the Table 4 to examine the effect of retail store formats on the customer buying behaviour using Chi-Square $\left(\chi^{2}\right)$ test. According to Anne F. Maben (2005), Chi-square $\left(\chi^{2}\right)$ test is used to determine whether there is a significant difference between the expected frequencies and the observed frequencies in one or more categories.

Table 4. Chi Square Test

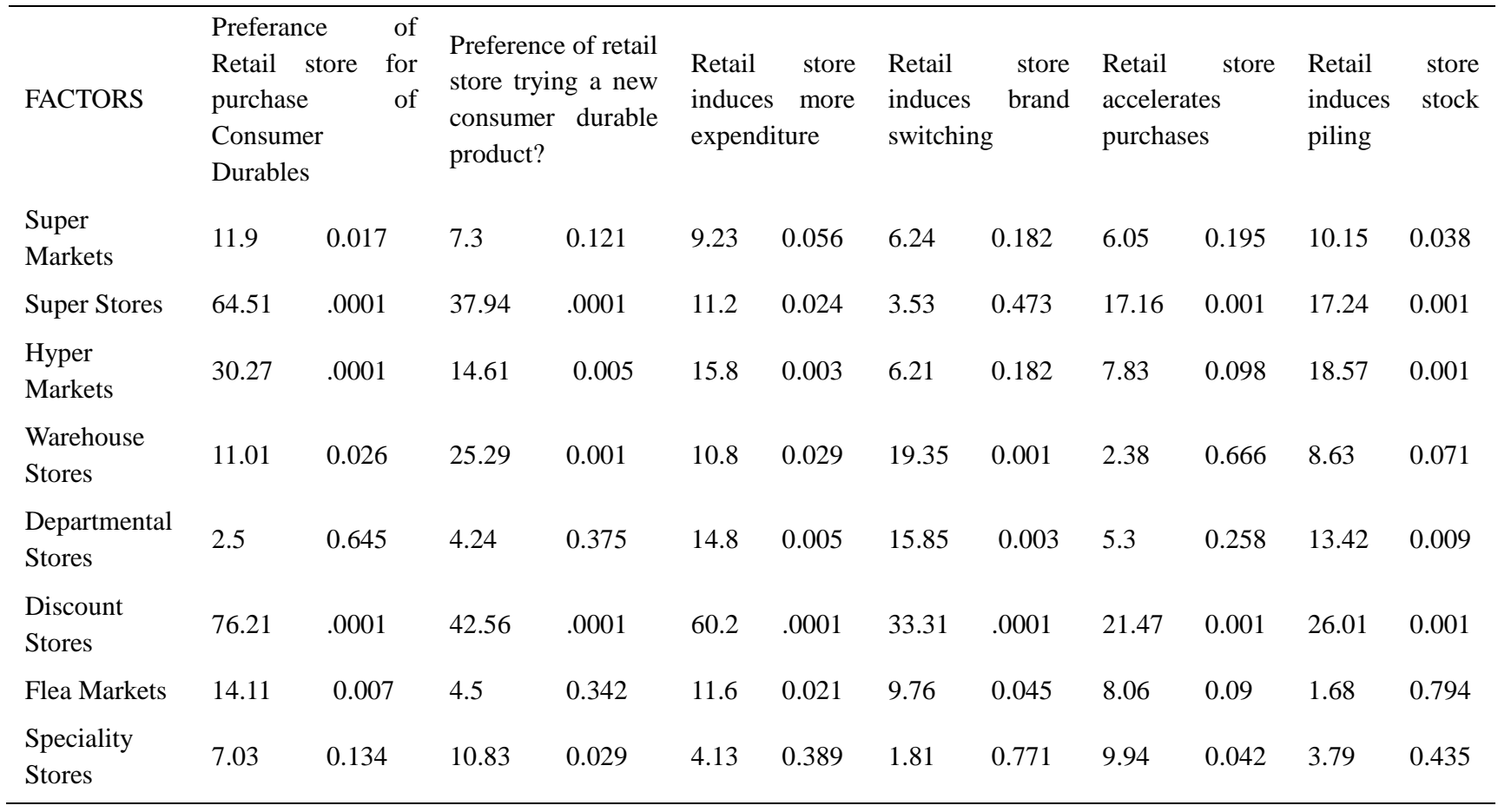

It is reflected in the table that the respondents prefer to visit Superstores, Discount Stores and Hypermarkets to purchase consumer durable products. This result is statistically significant since $p<0.05$. However it is evident from the chi square value (2.5) and (7.03) that Departmental Stores and Specialty Stores respectively are not preferred retail format of the consumers for the purchase of consumer durables.

The Chi square value $\left(\chi^{2}=42.56\right)$ signifies that the Discount Stores followed by the Super Stores $\left(\chi^{2}=37.94\right)$ are the most preferred retail store formats of the consumers for trying a new consumer durable product. Conversely the $p$-value $>0.05$ at Departmental Stores (0.375) Flea markets (0.342) and Super Markets 0.121 reflect that their influence is insignificant and not preferred by the consumers for the purchase of consumer durables.

The study approves that except Discount Stores $\left(\chi^{2}=60.22\right)$, no other store have a significant impact in tempting the consumers for more expenditure.

It is discovered that Discount Stores $\left(\chi^{2}=33.31\right)$ followed by Warehouse Stores $\left(\chi^{2}=19.35\right)$ have the most significant impact on the customers that induces them to change their brand of consumer durables. The study also suggests that the Specialty Stores ( $p$-value (0.771) have the least impact on consumer's brand shifting followed by Super Stores, (0.473) Hypermarkets (0.182) and Supermarkets (0.182)

It is established from the study that the Discount Stores $\left(\chi^{2}=21.47\right)$, has a significant impact on the consumers to accelerate their purchase of the consumer durables. It is evident from the data that the Super Stores $\left(\chi^{2}=60.22\right)$ and Hypermarkets $\left(\chi^{2}=60.22\right)$ have significant impact on the consumers to pile a stock of consumer durables. However Flea Markets (0.794) and specialty stores (0.435) lack to create an impact on the consumers to pile a stock of Consumer durables.

\subsection{Z Test}

The one-independent sample $\mathrm{z}$ test is a statistical procedure used to test hypotheses concerning the mean in a single population with a known variance. $Z$ Test was conducted to evaluate the significant impact of each retail store format considered in this research, on the customer buying behaviour in South Africa. 
Table 5. Z-Test Scores for Individual Retail Stores

\begin{tabular}{llll}
\hline S.NO. & TYPES OF STORES & Z score & $p$ value \\
\hline 1 & Super Market & -0.82 & 0.4122 \\
2 & Super Stores & 3.82 & 0.0001 \\
3 & Hypermarkets & -2.55 & 0.0108 \\
4 & Warehouse Stores & -2.09 & 0.0366 \\
5 & Departmental Stores & 0.82 & 0.4122 \\
6 & Flea Market & 1.55 & 0.1211 \\
7 & Discount Stores & 4.91 & 0.0001 \\
8 & Speciality Store & -1.36 & 0.1738 \\
\hline
\end{tabular}

It is exhibited in the Table 5 that Discount Stores, Super Stores, Hypermarkets and Warehouse Stores have significant impact on the customer buying behaviour of consumer durables. Where as Specialty Stores, Flea Markets, Departmental Stores and Super Markets that are having $p$ value (0.1738), (0.1211), (0.4122), and (0.4122) respectively, don't have a significant effect on the customer buying behaviour of consumer durables in South Africa.

In order to understand and study the overall effect of retail store formats on customer buying behaviour, the researcher decided to use the $\mathrm{z}$ test for a nondirectional, or two-tailed test, where the alternative hypothesis is stated as not equal to $(\neq)$ the null hypothesis.

Table 6. Z Test - Determination of the Critical Value

\begin{tabular}{lllllll}
\hline $\mathbf{X}$ & $\mathbf{f}^{\prime}$ & $\mathbf{F}$ & $\mathbf{d}=(\mathbf{X}-\mathbf{X})$ & $\mathbf{d}^{\mathbf{2}}$ & $\mathbf{f}^{*} \mathbf{d}^{2}$ & $\mathbf{f}^{*} \mathbf{X}$ \\
\hline $\mathbf{1}$ & 99.38 & 99 & -2 & 4 & 396 & 99 \\
$\mathbf{2}$ & 120 & 120 & -1 & 1 & 120 & 240 \\
$\mathbf{3}$ & 142.88 & 142 & 0 & 0 & 0 & 426 \\
$\mathbf{4}$ & 134.13 & 134 & 1 & 1 & 134 & 536 \\
$\mathbf{5}$ & 79.63 & 80 & 2 & 4 & 320 & 400 \\
Total & & $\mathbf{5 7 5}$ & $\mathbf{0}$ & $\sum \mathbf{d}^{2}=\mathbf{1 0}$ & $\mathbf{9 7 0}$ & $\mathbf{1 7 0 1}$ \\
& & & & & $\sum \mathrm{f}^{*} \mathrm{~d}^{2}=948$ & $\sum \mathrm{F}^{*} \mathrm{X}=1701$ \\
\hline
\end{tabular}

$$
\begin{aligned}
& \sigma \mathrm{x}=\sqrt{ } \sum \mathrm{d}^{2} /(\mathrm{n}-1), \text { Where } \mathrm{d}^{2}=(\mathrm{X}-\mathrm{X})^{2} \\
& \sigma \mathrm{x}=0.02 \\
& \mu=\sum \mathrm{f}^{*} \mathrm{X} / \mathrm{n}=2.95 \\
& \mathrm{Z}=(\mathrm{X}-\mu) / \sigma \mathrm{x}=2.5 \\
& \mathbf{Z}=\mathbf{2 . 5}
\end{aligned}
$$

In the study by Privitera (2015), we place the level of significance in both tails of the sampling distribution. In Table 6, we were therefore interested in any alternative from the null hypothesis. The researcher studied the one-independent sample $\mathrm{z}$ test and determined the critical value, we retained the null hypothesis at a 0.05 level of significance $(\alpha=.05)$.

From the calculations above, the findings of the Z-test confirms that the null hypothesis is rejected, because the value of $\mathrm{Z}$ is significant at (0.05) level of significance. Consequently the alternate hypothesis is established. It is confirmed from the above test that overall retail store formats have a significant effect on the customer buying behaviour of consumer durables in South Africa.

\section{Discussions on the Findings of the Study}

The empirical research findings above establish that the retail store formats have a significant effect on the customer buying behaviour. However all the retail store formats do not have a significant effect and the level of effect also varies. Retail store formats like Discount Stores and Warehouse stores have a significant effect on the customer buying behaviour whereas Flea Markets have an insignificant effect. These findings upholds the suggestions made by Hansen et al (2012) where they submit that there can be a number of different dimensions which are potentially significant for the customer's assessment of individual stores.

Correlation coefficients evaluate the strength of association between two variables. In the study, the correlation between most of the variables of the customer behaviour is positive. This means that when the value of one variable increases the value of other variables also tend to increase. However in most of the retail stores except the Flea Markets, 
the degree of relationship of Variable (VE) i. e. Retail Store accelerates purchases, has insignificant relationships with other variables. This establishes that there is no apparent relationship between the VE variable of customer behaviour and other variables of customer behaviour. It is also noteworthy that even Variable (VF) i.e. Retail Store induces stock piling, does not have a significant degree of relationship with other variables in case of Super Stores, Departmental Stores and Speciality Stores.

The study by Sinha and Kar (2007) wherein they argue that a number of retailers are in a mode of experimentation and trying several formats is further deliberated by the results of this study that clearly indicates that Discount Stores, Super Stores, Hypermarkets and Warehouse Stores have significant impact on the customer buying behaviour of consumer durables. Where as Specialty Stores, Flea Markets, Departmental Stores and Super Markets have an insignificant effect.

The current thinking as evidenced by the study of Singh et al (2014) suggests that retail store atmospherics \& design is highly associated with future consumption behaviour in terms of the customers' intention to visit, purchase. The results of this study approves these suggestions by going a step further and indicating that Super Stores, Discount Stores and Hyper Markets are favoured by customers to purchase consumer durables while Discount Stores and Super Stores are preferred with an intention to try new products in the category.

\section{Limitations}

The research study is not free from limitations, for example the sample was collected using convenience-sampling method from Gauteng province of South Africa and hence the research findings can only be applied to the South African context and cannot be generalized. Additionally, the research findings are restricted to the consumer durables market only and the results may not hold true for other categories of products. The retail store environment of South Africa is changing very fast and the research study findings of 2016 may not hold good in the years to come.

\section{Conclusions}

The effect of retail formats on the customer buying behaviour in the consumer durables market of South Africa was examined in this study. The degree of relationship between the key mediating variables of Customer buying behaviour was studied and evaluated. It is confirmed that most of the variables have a positive correlation with other variables of customer behaviour. However in some cases, variables have significant inverse relationship with each other. The study revealed that overall Variable (VE) had insignificant correlation with most of the variables. This showcases that retail stores of South Africa have lesser effect on accelerating the purchase of Consumer durables. The reason behind the insignificant relationship can also be considered as further scope of research. Further it is also important to note that in some cases, Variable (VF) also has insignificant correlation with some of the variables, which confirms that Departmental Stores, Super Stores and Specialty Stores of South Africa makes lesser effect on stock piling decision of consumer durables.

The study revealed that, there is significant relationship between Superstores/Discount Stores/Hypermarkets and buying of consumer durable products; there is insignificant relationship between Departmental Stores/Specialty Stores and buying of consumer durables; there is significant relationship between Discount Stores/Super Stores and trying new consumer durables; there is insignificant relationship between Departmental Stores/ Flea Markets/Super Markets and trying new consumer durables; there is a significant relationship between Discount Stores and spending more; there is significant relationship between Discount Stores/Warehouse Stores and switching brands; there is insignificant relationship between Specialty Stores/Super Stores/Hyper Markets/ Super Markets and switching brands; there is significant relationship between Discount Stores and purchase acceleration; there is significant relationship between Super Stores/Hyper Markets and piling of stock; and there is insignificant relationship between Flea Markets/Specialty Stores and piling of stock.

The study concludes that there is significant effect of Discount Stores, Super Stores, Hypermarkets and Warehouse Stores on the customer buying behaviour in the consumer durables market of South Africa.

The study thus proposes that it could be to the advantage of retailers of consumer durables in South Africa to understand the relationship between retail store formats and the customer buying behaviour variables. The retailers may select a suitable retail format to have a desired effect on the customer.

\section{References}

Anne, F. M. (2005). Statistics for the Social Science, SAGE Publications.

Baker, J., Levy, W., \& Grewal, D. (1992). An Experimental Approach to Making Retail Store Environmental Decisions. Journal of Retailing, 68(4), 445-460.

Bell, D. R., Ho, T., \& Tang, C. S. (1998). Determining Where to Shop: Fixed and Variable Costs of Shopping. Journal of Marketing Research, 35, 352-369. https://doi.org/10.2307/3152033 
Bellini, S., \& Cardinali, M. G. (2015). A Consumer Perspective on Grocery Retailers Differentiation.International Business Research, 8(8), 129-140. https://doi.org/10.5539/ibr.v8n8p129

Cronbach, L. (1951). Coefficient alpha and the internal structure of tests. Psychomerika, 16, $297-334$. https://doi.org/10.1007/BF02310555

Fox, E. J., Postrel, S., \& McLaughlin, A. (2007). The Impact of Retail Location on Retailer Revenues: An Empirical Investigation.Unpublished manuscript, Edwin L. Cox School of Business, Southern Methodist University, Dallas, $T X$.

Gregory, J. P. (2015). Statistics for the Behavioral Sciences, AGE Publications, Inc.

Grewal, D., Krishnan, R., Baker, J., \& Borin, N. (1998). The Effect of Store Name, Brand Name and Price Discounts on Consumers' Evaluations and Purchase Intentions. Journal of Retailing, 74(3), 331-352. https://doi.org/10.1016/S0022-4359(99)80099-2

Hansen, T., Cumberland, F., \& Solgaard, H. S. (2012). How the Measurement of Store Choice Behaviour Moderates the Relationship between Distance and Store Choice Behaviour. International Marketing Trends Conference, Paris, January.

Kearney, A. T. (2014). Seizing Africa's Retail Opportunities. The 2014 African Retail Development Index. Retrieved from

https://www.atkearney.com/documents/10192/4371960/Seizing+Africas+Retail+Opportunities.pdf/730ba912-da69 $-4 \mathrm{e} 09-9 \mathrm{~b} 5 \mathrm{~d}-69 \mathrm{~b} 063 \mathrm{a} 3 \mathrm{f} 139$

Kiran, R., \& Jhamb, D. (2011). A Strategic Framework for Consumer Preferences towards Emerging Retail Formats. Journal of Emerging Knowledge on Emerging Markets, 3, 437- 453. https://doi.org/10.7885/1946-651x.1058

Leszczyc, P. T. L. P., Sinha, A., \& Timmermans, H. J. P. (2000). Consumer Store Choice Dynamics: An Analysis of the Competitive Market Structure for Grocery Stores. Journal of Retailing, 76(3), 323-345. https://doi.org/10.1016/S0022-4359(00)00033-6

Levy, M., \& Weitz, B. A. (2002). Retailing Management, Tata McGraw Hill, Fourth Edition.

Liao, Y. Y., Liaw, G. F., \& Jen, F. (2011). How Cues in the Multiple Store Environment Influence Shopping Mood and Patronage Satisfaction? Journal of International Management Studies, 6(1).

Marais, H. T., Klerk, N. D., \& Dye, A. L. B. (2014). Perceived Effectiveness of Sales Promotion Techniques amongst South African Generation Y Students. Mediterranean Journal of Social Sciences, 5(21), 51-59.

Messinger, P. R., \& Narsimhan, C. (1997). A model of retail formats based on consumer's economizing on shopping time. Marketing Science, 16(1), 1-23. https://doi.org/10.1287/mksc.16.1.1

Mohsen, T., \& Reg, D. (2011). Making sense of Cronbach's alpha, International Journal of Medical Education, 2(5), 31-33.

Nguyen, H. H., Vu, P., \& Zhang, X. (2010). An Exploration Of Store Attribute Salience On Store Choice Behaviour In An Emerging Market- The Case Of Vietnam Grocery Market. International Marketing and Brand Management.

Shi, Z., Cheung, K., \& Prendergast, G. (2005). Behavioural Response to Sales Promotion Tools- A Hong Kong Study. International Journal of Advertising, 24(4), 467-486. https://doi.org/10.1080/02650487.2005.11072939

Singh, P., Katiyar, N., \& Verma, G. (2014). Retail Shoppability: The Impact of Store Atmospherics \& Store Layout on Consumer Buying Patterns. International Journal of Scientific \& Technology Research, 3(8), 15-23.

Sinha, P. K., \& Kar, S. K. (2007). An Insight into the Growth of New Retail Formats in India. IIM Ahmedabad, W.P. 2007-03-04.

\section{Copyrights}

Copyright for this article is retained by the author(s), with first publication rights granted to the journal.

This is an open-access article distributed under the terms and conditions of the Creative Commons Attribution license which permits unrestricted use, distribution, and reproduction in any medium, provided the original work is properly cited. 